\title{
GYDYTOJO ODONTOLOGO PADE்JĖJO MOTYVACIJĄ IR PASITENKINIMĄ DARBU LEMIANTYS VEIKSNIAI LIETUVOJE IR KIPRE
}

\author{
Akvilè Marčiulionytė, Daiva Kerienė, Danguolè Grūnovienė, Daiva Mačiulienė \\ Kauno kolegijos Medicinos fakultetas
}

Raktažodžiai: gydytojo odontologo padejejjas, motyvacija, motyvas, pasitenkinimas darbu.

\begin{abstract}
Santrauka
Vienas iš svarbiausių veiksnių, lemiančių pasitenkinimą darbu, yra darbuotojų motyvacija. Motyvacija skatina siekti karjeros ir užbrèžtų tikslų. Neįmanoma nepastebėti santykio tarp pasitenkinimo darbu ir motyvacijos. Sèkmès siekiančios organizacijos turi ivvertinti abiejų sričių - motyvacijos ir pasitenkinimo darbu tarpusavio ryši ir î igyvendinti savo darbuotojų siekius. Tai svarbiausias organizacinès veiklos tikslas [2]. Šalyje trūkstant gydytojo odontologo padejjeju, Lietuvos odontologinès priežiūros įstaigoms ne visada pavyksta suformuoti tinkamą komandą, todèl svarbu išsiaiškinti, kaip patenkinti gydytojo odontologo padejejjų poreikį darbo rinkoje. Tyrimu siekta atskleisti gydytojo odontologo padejejų motyvaciją ir pasitenkinimą darbu lemiančius veiksnius Lietuvoje ir Kipre. Tyrime dalyvavo 140 Lietuvos ir 48 Kipro gydytojo odontologo padejjejai. Tyrimo tikslui pasiekti vykdyta apklausa raštu (internetu). Klausimai suskirstyti i uždaro ir atviro tipo (kokybinius). Tyrimo rezultatai atskleidè, kad abiejų šalių respondentai mano, jog darbo užmokesčio didinimas yra efektyviausia motyvacijos priemonè, pritaria, ypač Kipro respondentai, kad stiprus motyvatorius - kvalifikacijos kèlimo kursai, mokymai. Lietuvos ir Kipro respondentai yra patenkinti darbu ir igyta gydytojo odontologo padejejjo profesine kvalifikacija, gerais santykiais su vadovu, malonia atmosfera, darbe jaučiasi saugiai. Lietuvoje gydytojo odontologo padejējų pasitenkinimą darbu labiausiai lemia atlygis. Kipre didžiausias pasitenkinimo darbu veiksnys - darbinè atmosfera. Kipro respondentai stresą patiria dažniau, nei Lietuvos, bet darbe jie jaučiasi labiau pripažinti. Svarbiausiais motyvacijos veiksniais Lietuvos respondentai išskyrè tobulejjimo galimybes, o Kipro - pripažinimą.
\end{abstract}

\section{Ivadas}

Pasitenkinimas darbu - didelio psichologijos mokslų atstovų susidomèjimo sulaukusi tyrinèjimų sritis, apibūdinanti žmogaus pasitenkinimą savo darbu. Pasitenkinimas darbu susideda iš daugelio tarpusavyje susijusių asmeninių, darbo ar nuo vadovų priklausomų veiksnių, tokių kaip amžius, lytis, darbuotojo charakteris, išsilavinimas, darbo sąlygos, darbo užmokestis ir kita [6]. Skatinant darbuotojų pasitenkinimą darbu, svarbu žinoti, kad jis atsiranda išorinių ir vidinių veiksnių sandūroje. Kartais pasitenkinimas ar nepasitenkinimas darbu yra pastovus žmogaus bruožas, susijęs su vidiniais veiksniais - asmens ypatybėmis. Sėkmès siekiančios organizacijos turi įvertinti abiejų sričių - motyvacijos ir pasitenkinimo darbu tarpusavio ryšį ir ịgyvendinti darbuotojų siekius. Tai svarbiausias organizacinès veiklos tikslas [2].

Sveikatos priežiūros specialistų bendravimas, komandinis darbas ir komunikavimas yra svarbus saugiai ir efektyviai teikti sveikatos priežiūros paslaugas [8]. Gydytojo odontologo padejejjas privalo asistuoti ịvairių specializacijų gydytojams odontologams, burnos higienistams, atpažizstant gyvybei pavojingas būkles ir tinkamai $i$ jas reaguojant, teikiant būtinają medicinos pagalbą, atliekant ịvairias odontologinio gydymo procedūras, atpažịstant ịvairių pacientų grupių burnos ir dantų ligas. Jam tenka bendrauti ir bendradarbiauti su sveikatos priežiūros specialistais, laikantis profesinès etikos ir pilietiškumo principų, užtikrinant ịrodymais grịstos odontologijos praktikos kokybę, praktineje gydytojo odontologo padejejjo veikloje kurti naujas idejjas, prisitaikyti prie naujų situacijų, stiprinant profesijos įvaizdị, rūpinantis jos verte ir reikšmingumu visuomenėje, komunikuojant profesinėje aplinkoje.

Nemažai autorių motyvacijos sąvoką sieja su asmens poreikiais ir motyvais, nuo kurių priklauso individo veiksmai ir elgesys darbe. Pasak V. Baršauskienès ir B. Janulevičiūtės Ivaškevičienès (1999), motyvacija - elgesio skatinimo sistema, kurią sukelia motyvai, tokie kaip skatinamoji priežastis, veiksnys, irodymas ir argumentas bei vidinis veiksnys, kuris skatina kokią nors veiklą [10]. Poreikis yra motyvaci- 
jos pagrindas, sukeliantis psichologini jausmą, kad žmogui kažko reikia. Poreikiai yra pagrindiniai elementai, lemiantys didejjančio pasitenkinimo lygi [4]. Motyvuoti ir savo darbu patenkinti darbuotojai našiau dirba, o tai lemia ju teikiamu paslaugų kokybę. Kiekvienai sveikatos priežiūros įstaigai svarbu turèti motyvuotą personalą, nes tik toks specialistas gali pasiekti gerų darbo rezultatų. Gydytojo odontologo padèjëjas, būdamas patenkintas savo darbo aplinka, turés didesnę ịtaką darbo rezultatų gerinimui [3]. Sveikatos specialistų motyvacija darbe gali turèti įtakos sveikatos paslaugų teikimui, tačiau šiam svarbiam darbo aplinkos veiksniui organizacijose paprastai neskiriama reikiamo dèmesio [9].

Išanalizavus mokslinę literatūrą apie gydytojo odontologo padejjëjo pasitenkinimą darbu ir motyvaciją, Kipre šia tema atliktų tyrimų rasti nepavyko. Galbūt todèl, kad gydytojo odontologo profesija Kipre nèra reglamentuota ar labai paklausi [1]. Apžvelgus kitų sveikatos priežiūros specialistų tyrimų, susijusių su motyvacija ir pasitenkinimo darbu rezultatus, sveikatos priežiūros specialistus labiausiai motyvuoja vidiniai veiksniai. Labiausiai motyvuoja asmeniniai pasiekimai, atlyginimas, ryšys su kolegomis ir darbo sąlygos [5].

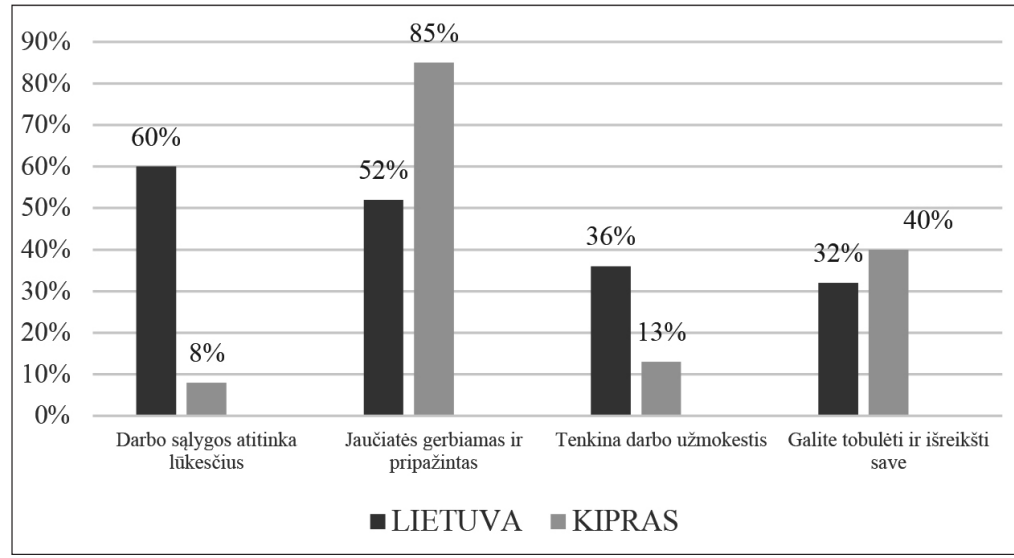

1 pav. Respondentų darbo pasirinkimo priežastys Lietuvoje $(\mathrm{N}=140)$ ir Kipre $(\mathrm{N}=48)$

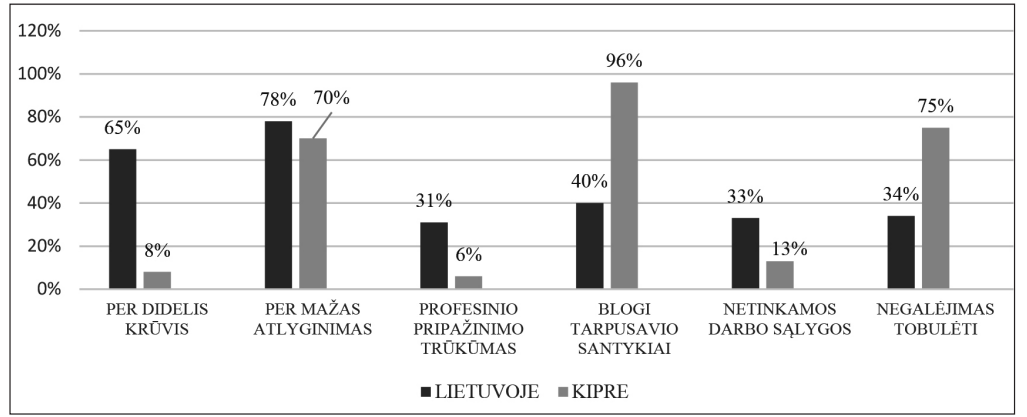

2 pav. Respondentų nepasitenkinimą darbu lemiantys veiksniai Lietuvoje ( $N=140)$ ir $\operatorname{Kipre}(\mathrm{N}=48)$
Motyvacija ir pasitenkinimas darbu - vienos iš labiausiai aptariamų organizacinio elgesio temų, kuriomis per daugeli metu atlikta daugybè tyrimų. Pasitenkinimas darbu reiškia malonumą, kurị darbas teikia asmeniui. Motyvacija reiškia tik priežastí, dèl kurios asmuo atlieka savo darbą, neatsižvelgiant ị tai, ar darbas jam teikia malonumą. Motyvacija ir pasitenkinimas yra glaudžiai susiję, nes pasitenkinimą darbu galima apibūdinti kaip motyvacijos tipą. Dauguma Lietuvos respondentų pasitenkinimą darbu nurodè kaip svarbiausią aspektą, siekiant pripažinimo, pajamų, paaukštinimo ir kitų tikslų, teikiantị visaavertiškumo jausmą. Mažos dalies nuomone, tai individo požiūris ị darbą, kuris priklauso nuo asmenybès bruožų. Kipro respondentams pasitenkinimas darbu - tai materialiujų ir psichologinių poreikių patenkinimo rezultatas; maža dalis nurodè, jog tai pagrindinis motyvacijos šaltinis ir paskata siekti geresnių darbo rezultatų.

Tyrimo tikslas - atskleisti gydytojo odontologo padèjèjų motyvaciją ir pasitenkinimą darbu lemiančius veiksnius Lietuvoje ir Kipre.

\section{Tyrimo objektas ir metodai}

Šiuo tyrimu siekta ịvertinti priežastis, dèl kurių gydytojo odontologo padejejjai dirba pasirinktoje įstaigoje. Siekiant tyrimo tikslo, vykdyta Lietuvos ir Kipro gydytojo odontologo padejejjų apklausa raštu (internetu), apimanti uždaro ir atviro tipo (kokybinius) klausimus. Tyrime dalyvavo 140 Lietuvos ir 48 Kipro gydytojo odontologo padejjejai.

\section{Tyrimo rezultatai}

ES šalyse burnos sveikatos priežiūros specialistų veiklos reikalavimai yra panašūs, todèl Lietuvos ir Kipro gydytojo odontologo padejjejo veikloje ir pasitenkinime darbu stebima panašumų ir skirtumų. Abiejų šalių respondentai patenkinti savo darbu; sutinka, kad jų darbas svarbus kitiems žmonèms; patinka igyta specialybė; santykiai su vadovu geri; darbe jaučiasi gerai ir saugiai, tačiau Kipro respondentai dažniau patiria stresą, o didžiosios dalies Lietuvos respondentų netenkina gaunamas atlygis (1 pav.).

Lietuvos respondentai nurode, kad pagrindiniai nepasitenkinimą darbu lemiantys veiksniai yra per mažas atlyginimas ir per didelis darbo krūvis. Mažiausiai nepasitenkinimui darbu įtakos turi negalejjimas tobulèti, netinkamos darbo sąlygos ir profesinio pripažinimo trūkumas. Didžiausia dalis Kipro respondentų vienareikšmiškai teigia, jog labiausiai nepasitenkinimą darbu lemia blogi tarpusavio san- 
tykiai, o mažiausiai - profesinio pripažinimo trūkumas (2 pav.).

Daugiausia Lietuvos respondentų motyvuoja pripažinimas (3 pav.), beveik trečdalis teigia, kad motyvaciją lemia sékmè ir atsakomybe ir tik mažumos nuomone: gera atmosfera, paskatos, normuotos darbo valandos, atlyginimas. Daugumos Kipro respondentu motyvaciją labiausiai skatina tobulejjimo galimybès, o mažumos - atsakomybè.

Lietuvos respondentų darbo įstaigose dažniausiai taikomos motyvacijos priemonès - bendros darbuotojų šventès, nors ketvirtadalis nurodè, jog jokios priemonès netaikomos. Kipro respondentų darbo ịstaigose dažniausiai taikoma motyvacijos priemone - darbo užmokesčio didinimas (4 pav.).

Mokslinèje literatūroje išskiriamos socialinès, ekonominès, piniginès, teisinès, psichologinès darbuotojų motyvavimo priemonès. Darbo užmokestis yra viena iš geriausiai žinomų ir plačiausiai taikomų motyvavimo priemonių (1 lentelè). Nemažą motyvuojantị poveikị turi fizinès darbo sąlygos, psichologinès priemonès (organizacijos prestižas, užimtumo garantijos, profesinio tobulinimosi galimybės); stiprus motyvatorius - teigiamas socialinis-psichologinis klimatas, su darbu susijusios informacijos perdavimas, operatyvus konfliktinių situacijų sprendimas, dėmesys darbuotojams. Nustatyta, kad abiejų šalių respondentai mano, jog darbo užmokesčio didinimas yra efektyviausia motyvacijos priemoné, respondentai, ypač Kipro, pritaria, kad stiprus motyvatorius - kvalifikacijos kèlimo kursai,

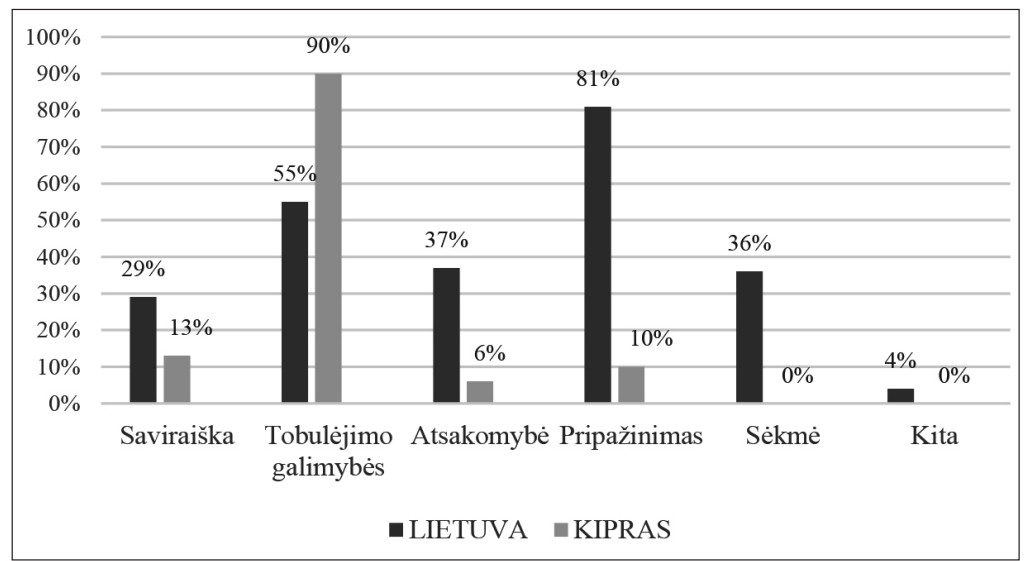

3 pav. Respondentų pasitenkinimą darbu skatinantys veiksniai Lietuvoje $(\mathrm{N}=140)$ ir $\operatorname{Kipre}(\mathrm{N}=48)$

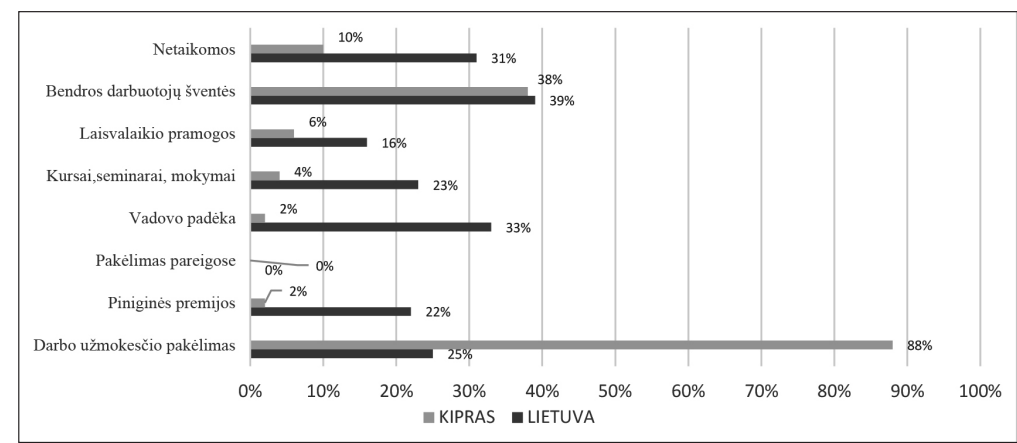

4 pav. Respondentų nuomonė apie motyvacijos priemones jų darbo ịstaigoje Lietuvoje $(\mathrm{N}=140)$ ir Kipre $(\mathrm{N}=48)$

mokymai (2 lentelè). Dèl motyvavimo priemonės „darbo sąlygų gerinimas" nuomonès šiek tiek išsiskyrè.

Respondentų nuomone, labiausiai efektyvios motyvacijos priemonės yra darbo užmokesčio didinimas bei kvalifikacijos kèlimo kursai, moky-
1 lentelè. Respondentų nuomonè apie motyvacijos priemonių efektyvumą Lietuvoje $(\mathrm{N}=140)$

\begin{tabular}{|l|c|c|c|c|}
\hline $\begin{array}{l}\text { Motyvacijos prie- } \\
\text { moné }\end{array}$ & $\begin{array}{c}\text { Neefek- } \\
\text { tyvu }\end{array}$ & $\begin{array}{c}\text { Nelabai } \\
\text { efektyvu }\end{array}$ & $\begin{array}{c}\text { Efek- } \\
\text { tyvu }\end{array}$ & $\begin{array}{c}\text { Labai } \\
\text { efektyvu }\end{array}$ \\
\hline $\begin{array}{l}\text { Kvalifikacijos kè- } \\
\text { limo kursai, moky- } \\
\text { mai }\end{array}$ & $2 \%(3)$ & $7 \%(10)$ & $\begin{array}{c}\mathbf{6 1 \%} \\
(85)\end{array}$ & $\begin{array}{c}30 \% \\
(42)\end{array}$ \\
\hline $\begin{array}{l}\text { Darbo užmokesčio } \\
\text { didinimas }\end{array}$ & $1 \%(2)$ & $4 \%(5)$ & $\begin{array}{c}26 \% \\
(36)\end{array}$ & $\begin{array}{c}\mathbf{6 9 \%} \\
(97)\end{array}$ \\
\hline $\begin{array}{l}\text { Darbo sąlygu geri- } \\
\text { nimas }\end{array}$ & $1 \%(2)$ & $4 \%(5)$ & $\begin{array}{c}32 \% \\
(45)\end{array}$ & $\begin{array}{c}\mathbf{6 3 \%} \\
(88)\end{array}$ \\
\hline $\begin{array}{l}\text { Karjeros galimybės } \\
\text { Dažnesni viso ko- }\end{array}$ & $1 \%(2)$ & $6 \%(8)$ & $\begin{array}{c}34 \% \\
(48)\end{array}$ & $\begin{array}{c}\mathbf{5 9 \%} \\
(82)\end{array}$ \\
\hline $\begin{array}{l}\text { lektyvo susitikimai, } \\
\text { išvykos }\end{array}$ & $21 \%(30)$ & $\begin{array}{c}\mathbf{6 0 \%} \\
(84)\end{array}$ & $\begin{array}{c}18 \% \\
(25)\end{array}$ \\
\hline
\end{tabular}

2 lentelè. Respondentų nuomonè apie motyvacijos priemonių efektyvumą Kipre $(\mathrm{N}=48)$

\begin{tabular}{|l|c|c|c|c|}
\hline $\begin{array}{l}\text { Motyvacijos } \\
\text { priemonė }\end{array}$ & $\begin{array}{c}\text { Neefekty- } \\
\text { vu }\end{array}$ & $\begin{array}{c}\text { Nelabai } \\
\text { efektyvu }\end{array}$ & $\begin{array}{c}\text { Efekty- } \\
\text { vu }\end{array}$ & $\begin{array}{c}\text { Labai } \\
\text { efektyvu }\end{array}$ \\
\hline $\begin{array}{l}\text { Kvalifikacijos } \\
\text { kėlimo kursai, } \\
\text { mokymai }\end{array}$ & $0 \%$ & $1 \%(1)$ & $8 \%(4)$ & $\mathbf{9 1 \% ( 4 3 )}$ \\
\hline $\begin{array}{l}\text { Darbo užmokes- } \\
\text { čio didinimas }\end{array}$ & $1 \%(1)$ & $0 \%$ & $8 \%(4)$ & $\mathbf{9 1} \%(43)$ \\
\hline $\begin{array}{l}\text { Darbo sąlygu } \\
\text { gerinimas }\end{array}$ & $1 \%(1)$ & $1 \%(1)$ & $\mathbf{9 6} \%(46)$ & $4 \%(2)$ \\
\hline $\begin{array}{l}\text { Karjeros gali- } \\
\text { mybės }\end{array}$ & $1 \%(1)$ & $1 \%(1)$ & $\mathbf{9 4} \%(45)$ & $4 \%(2)$ \\
\hline $\begin{array}{l}\text { Dažnesni viso } \\
\text { kolektyvo susi- } \\
\text { tikimai, išvykos }\end{array}$ & $25 \%(12)$ & $\mathbf{6 7 \% ( 3 2 )}$ & $4 \%(2)$ & $4 \%(2)$ \\
\hline
\end{tabular}


mai; neefektyviausios, ypač Kipro respondentų nuomone, - dažnesni viso kolektyvo susitikimai, išvykos (1,2 lentelès).

Daugumos Lietuvos respondentų nuomone, darbo sąlygos atitinka lūkesčius, beveik pusè jaučiasi gerbiami ir pripažinti, trečdalis gali tobulèti ir išreikšti save. Kipre didžioji dauguma jaučiasi gerbiami ir pripažinti, beveik pusé dirba dèl to, kad dirbdami įstaigoje gali tobulèti ir išreikšti save.

\section{Išvados}

1. Abiejų šalių respondentai patenkinti darbu ir igyta specialybe; sutinka, kad jų darbas svarbus kitiems žmonèms; darbe maloni atmosfera, jaučiasi saugiai ir gerai, geri santykiai su vadovu. Svarbiausias pasitenkinimo darbu veiksnys, Lietuvos respondentų nuomone, yra atlygis, nors didesnès respondentų dalies gaunamas atlygis netenkina; Kipro darbo atmosfera, beveik visi Kipro respondentai gaunamu atlygiu yra patenkinti.

2. Pagrindinis skirtumas tarp Lietuvos ir Kipro gydytojo odontologo padejjejų motyvacijos ir pasitenkinimo darbu yra tas, kad Kipro respondentai, skirtingai nei Lietuvos, darbe dažniau patiria stresą, bet jaučiasi labiau pripažinti. Skirtingas respondentų požiūris į darbą: Lietuvos respondentų nuomone - darbas sunkus ir reikalaujantis daug atsakomybès, o Kipro respondentams - iddomus.

3. Abiejų šalių respondentai mano, jog darbo užmokesčio didinimas yra efektyviausia motyvacijos priemonè. Lietuvos respondentai kaip labai efektyvią motyvavimo priemonę nurode darbo sąlygų gerinimą, o Kipro respondentams stipriausias motyvatorius - tobulèjimo galimybès.

\section{Literatūra}

1. Mishra PK. Job satisfaction. Iosr Journal of Humanities and Social Science 2013;14(5), 45-54.

https://doi.org/10.9790/1959-1454554

2. Dartey-Baah K, Harlley A. Job satisfaction and motivation: understanding its impact on employee commitment and organisational performance. Academic Leadership: The Online Journal 2010;8(4):39.

https://scholars.fhsu.edu/alj/vol8/iss $4 / 39$

3. Tamulienè R, Mačiulienė D, Žukauskaitė V. Gydytojų odontologų padèjèjų pasitenkinimas darbu ir jị lemiantys veiksniai. Sveikatos mokslai, 2016;26(6):231-236.

https://doi.org/10.5200/sm-hs.2016.122

4. Kamdron T. Work motivation: relationships with job satisfaction, locus of control and motivation orientation. International Journal of Liberal Arts and Social Sciences 2015; 3: 1-26 https:// www.researchgate.net/publication/305072649_Work_Motivation_Relationships_with_Job_Satisfaction_Locus_of_Control_ and_Motivation_Orientation

5. Grujičić M, Jovičić-Bata J, Rađen S, Novaković B, Šipetić-Grujičić $S$. Work motivation and job satisfaction of health workers in urban and rural areas. Vojnosanit Pregl 2016;73(8): 735-743.
https://doi.org/10.2298/VSP140715062G

6. Temesgen Wayuma Balcha Z, Ejigu Y, Weldegebreal F, Woldie M. Motivation of health workers and associated factors in public hospitals of West Amhara, Northwest Ethiopia. J Patient Prefer Adherence 2016; 10: 159-169.

https://doi.org/10.2147/PPA.S90323

7. Council of European Dentists. Manual of dental practice 2014 Cyprus. https://www.omd.pt/content/uploads/2017/12/cedmanual-2015-chipre.pdf

8. Lambrou P, Kontodimopoulos N, Niakas D. Motivation and job satisfaction among medical and nursing staff in a Cyprus public general hospital. Human Resources for Health 2010;8:26.

https://doi.org/10.1186/1478-4491-8-26

9. Jančauskas E. E. Žmogiškujų išteklių vadyba. Vilnius, 2011:116.

10. Baršauskienė V., Janulevičiūtè-Ivaškevičienė B. Žmogiškieji santykiai. KTU, 1999:387.

\section{FACTORS THAT AFFECTING \\ THE MOTIVATION AND JOB SATISFACTION OF A DENTAL ASSISTANT'S IN LITHUANIA AND CYPRUS}

\section{A. Marčiulionytė, D. Kerienė, D. Grūnovienė, D. Mačiulienė}

Keywords: dental assistants, motivation, job satisfaction.

Summary

Motivation - one of the most important determining satisfaction. Motivation encourages to reach career goals. It is impossible not to notice the relationship between job satisfaction and motivation. Organizations that want to be successful must evaluate both areas - motivation and job satisfaction and to realize the aspirations of employees. This is the most important part of organizational activities. According to data of Lithuanian Dental Chamber the biggest problem is lack of dental assistants. On of the most important tasks these days is to find out how to meet the need for dental assistants in the labor market. The aim of the research is to reveal the factors that affecting the motivation and job satisfaction of a dental assistant's in Lithuania and Cyprus. Participants: 140 Lithuanian dental assistants and 48 Cypriots dental assistants. Research method - online survey. The questions divided into closed and open type. The results of the study revealed that the most part of assistants partisipated in study, level of job satisfaction is low. Respondents from both countries considers that the most effective motivating tool is wage increases, respondents agree especially in Cyprus, that a strong motivator - courses, training. It was determined that $\mathrm{Li}$ thuanian and Cypriot respondents are satisfied with their job and have acquired the professional qualifications of a dental assistant, pleasant atmosphere at work because then they feels safe, good relationship with the manager. In Lithuania job satisfaction is mostly affecting by salary and in Cyprus - working atmosphere. Cypriot respondents feel stress more often than respondents from Lithuanian, but they feel more recognized at work. Lithuanian respondent singled out opportunities for improvement and Cyprus as the most important motivating factors.

Correspondence to: daiva.maciuliene@go.kauko.lt

Gauta 2020-10-06 